\title{
KARAKTERISTIK AMPLANG IKAN LELE DUMBO (Clarias gariepinus) HASIL VARIASI RASIO DAGING IKAN LELE DAN TAPIOKA
}

Characteristics of Dumbo Catfish Amplang Crackers Produced Under Different Ratio of Catfish Flesh and Tapioca

\author{
Priyanto Priyanto $^{1)}$, Yuli Wibowo ${ }^{2)}$, Jay Jayus ${ }^{3) *}$ \\ ${ }^{1)}$ Program Studi Magister Teknologi Agroindustri, Fakultas Teknologi Pertanian, Universitas Jember \\ ${ }^{2)}$ Program Studi Teknologi Industri Pertanian, Fakultas Teknologi Pertanian, Universitas Jember \\ ${ }^{3}$ Program Studi Teknologi Hasil Pertanian, Fakultas Teknologi Pertanian, Universitas Jember \\ *Korespondensi Penulis: jayus.ftp@unej.ac.id
}

\begin{abstract}
The demand for amplang crackers is now increasing. However, the price of its raw material, mackerel fish, is generally higher compare to other fishes, causing the higher cost of this type crackers production. Effort to explore other fish as an alternative raw material is required to overcome the problems. Catfish is one of the choices to be used as raw material since this fish is more available in a market in a lower price, but the protein properties of this fish is different to mackarel, which will be possible to affect the nature of the crackers obtained. To produce catfish amplang crackers to be similar to common amplang product, it is necessary to find out the right composition of catfish and tapioca flour used. Therefore, the purpose of this research was to characterize physico-chemically and organoleptically, the catfish amplang crackers made under different ratio of fish flesh and starch. The experiment was designed using completely randomized design. Physico-chemical data obtained were analyzed using ANOVA, while the organoleptic test data were examined using chi-square method. The effectiveness test was carried out to find the proper ratio of raw materials composition used. The results showed that the higher the ratio of the fish flesh and the starch composition, the lower the texture value of the crackers as an indication of the decrease of its crispness. Although the lightness of the crackers was lowered by the addition of more starch to the dough, its linear expansion and hygroscopicity were not affected. The results of organoleptic test showed that the panelist was prefer to a higher crispness of crackers. The most preferable cracker was the one with 1:2.25 ratio of catfish flesh and starch, showing the characteristic of $1.80 \%$ moisture, $2.08 \%$ ash, $5.75 \%$ protein, $23.55 \%$ fat, and $66.93 \%$ carbohydrate.
\end{abstract}

Keywords: cracker, catfish, tapioca starch

\section{PENDAHULUAN}

Harga ikan tengiri sangat mahal, berkisar antara Rp 60.000 sampai Rp 100.000 per ekor. Salah satu upaya mengatasi mahalnya ikan tengiri yaitu dengan menggunakan ikan lain sebagai alternatif bahan baku pembuatan amplang. Lele merupakan salah satu komoditas ikan yang potensial untuk digunakan dalam pembuatan amplang karena harganya relatif murah dibandingkan ikan tengiri. Ikan lele relatif mudah dibudidayakan dan jumlahnya yang sangat besar. Pertumbuhan rata-rata produksi ikan lele tahun 20152018 sebesar 56,32\%, dengan peningkatan produksi ikan lele tahun 2017-2018 dari 841,75 ribu ton menjadi 1,81 juta ton (114,82\%). Peningkatan tersebut dikarenakan adanya kegiatan bioflok (Kementerian Kelautan dan Perikanan, 2018).

Lele memiliki kandungan protein yang tinggi yaitu sebesar 18,7\% (Suyatno, 2010). Kandungan protein yang tinggi dan harga yang relatif lebih murah dibandingkan ikan tengiri menjadikan ikan lele dapat dijadikan pengganti ikan tengiri sebagai bahan baku pembuatan amplang.

Kandungan protein ikan lele tidak jauh berbeda dengan ikan tengiri. Menurut 
Nurilmala et al. (2009) ikan lele dumbo memiliki kadar protein sebesar 17,7-26,7\%; sedangkan ikan tengiri memiliki kandungan protein sebesar 28\%. Selain kandungan proteinnya, ikan lele juga mengandung karoten, vitamin A, fosfor, kalsium, zat besi, dan vitamin B1 (Rosa et al., 2007). Rohimah et al. (2014) menyebutkan bahwa komponen gizi ikan lele mudah dicerna dan diserap oleh tubuh. Dengan demikian sangat potensial untuk dikembangkan menjadi amplang. Kerupuk amplang lele dapat dihasilkan mirip dengan amplang tengiri, dengan komposisi variasi rasio daging ikan lele dan tapioka yang tepat. Pemanfaatan ikan lele dumbo hingga saat ini dibuat konsentrat protein ikan (Listyarini et al., 2018) dan amplang lele dengan perbedaan jenis tepung (Pradita, 2016).

Penelitian tentang pemanfaatan ikan lele dumbo menjadi amplang bertujuan untuk mengetahui karakteristik amplang menggunakan ikan lele sebagai pengganti ikan tengiri yang meliputi tekstur, nilai kecerahan, daya kembang, higroskopisitas, rendemen dan uji kesukaan serta kandungan gizi hasil perlakuan terbaik. Hasil penelitian ini dapat dijadikan sebagai referensi pembuatan amplang menggunakan ikan lele sebagai pengganti ikan tengiri yang harganya mahal.

\section{METODE PENELITIAN}

\section{Alat dan Bahan}

Alat-alat yang digunakan untuk pembuatan amplang meliputi kompor, wajan ukuran 16, food processor merk Vienta, blender merk Vienta. Alat yang digunakan untuk analisis kimia meliputi tabung khjeldal (merk Buchi), color reader (merk CR-10 minolta), oven (merk Selecta), tanur (merk Carbolite), neraca analitik (merk Ohaus), rheotex, dan seperangkat alat soxhlet.

Bahan utama dalam penelitian ini adalah lele dan tapioka. Jenis lele yang digunakan adalah lele dumbo dengan usia 2-3 bulan yang diperoleh di Kabupaten Bondowoso, dan tepung tapioka (Pak Tani). Bahan tambahan yang digunakan adalah telur ayam ras, air, bawang putih, soda kue, garam (Kapal Laut), gula pasir lokal, penyedap rasa, dan minyak goreng. Selain bahan-bahan tersebut digunakan bahan-bahan untuk menganalisis karakteristik kimia seperti $\mathrm{HCl}, \mathrm{H}_{2} \mathrm{SO}_{4}$, pelarut heksan, $\mathrm{NaOH}, \mathrm{H}_{3} \mathrm{BO}$, indikator metil merah, dan $\mathrm{NaCl}$.

\section{Tahapan Penelitian}

\section{Penyiapan Fillet Daging Lele Dumbo}

Fillet daging lele didapatkan melalui proses membuang kulit ikan, memisahkan daging ikan dari tulang, sirip, ekor dan kepala sehingga didapatkan fillet daging lele. Fillet daging lele ini selanjutnya dicuci dan diolah menjadi amplang lele.

\section{Pembuatan Amplang Lele}

Proses pembuatan amplang lele meliputi proses pencampuran fillet daging lele dengan bahan pembantu (putih telur 30 $\mathrm{g}$, minyak goreng $15 \mathrm{~g}$, bawang putih $3 \mathrm{~g}$, gula kristal putih 2,5 g, garam 1,5 g, penyedap $1 \mathrm{~g}$, dan soda kue 0,5 g) dan tepung tapioka. Selanjutnya dilakukan pencetakan adonan menggunakan plastik segitiga dengan diameter $1,50 \mathrm{~cm}$, penggorengan I sampai mengembang (2030 menit) dan dilanjutkan dengan penggorengan II sampai matang (20-30 menit). Amplang lele yang sudah matang diangkat dari minyak panas dan ditiriskan. Amplang lele dumbo kemudian diuji sifat fisik, kesukaan, dan kandungan gizinya.

\section{Rancangan Percobaan}

Penelitian ini menggunakan

rancangan acak lengkap (RAL) nonfaktorial. Penelitian dilakukan pengulangan sebanyak tiga kali ulangan dengan perlakuan yang ditunjukkan pada Tabel 1. 
Tabel 1. Perlakuan amplang lele dumbo

\begin{tabular}{lcc}
\hline Variasi & \multicolumn{2}{c}{ Rasio ikan dan tapioka } \\
\cline { 2 - 3 } sampel & Daging ikan lele & Tapioka \\
\hline P1 & 1 & 1,25 \\
P2 & 1 & 1,50 \\
P3 & 1 & 1,75 \\
P4 & 1 & 2,00 \\
P5 & 1 & 2,25 \\
\hline
\end{tabular}

Data yang diperoleh dari pengujian dianalisis menggunakan uji ANOVA pada taraf kepercayaan 5\%. Uji lanjutan menggunakan DNMRT sedangkan data organoleptik diolah menggunakan Chisquare $(\alpha=5 \%)$. Data disajikan dalam bentuk grafik dan tabel.

\section{Metode Analisis}

Karakteristik fisik amplang lele dumbo dianalisis nilai kecerahannya menggunakan alat color reader (Fardiaz, 1984), tekstur menggunakan rheotex. Analisis daya kembang, higroskopisitas, dan rendemen (AOAC, 2005). Selanjutnya uji kesukaan dengan uji hedonik 5 skala (Setyaningsih, 2010). Karakteristik kimia meliputi kadar air (AOAC, 2005), kadar protein (Sudarmadji et al., 1997), kadar lemak (AOAC, 2005), kadar abu (AOAC, 2005), dan kadar karbohidrat by difference (AOAC, 2005).

Uji kesukaan dilakukan dengan uji hedonik atau kesukaan (Setyaningsih, 2010) meliputi kerenyahan, warna, rasa dan keseluruhan. Pada pengujian tersebut diharapkan panelis tak terlatih yang berjumlah 40 orang disediakan 5 sampel amplang lele dan masing-masing sudah diberi kode 3 angka yang berbeda. Panelis mengisi kuisioner yang telah disediakan untuk memberikan penilaian yang tertinggi sampai terendah. Panelis dapat menggunakan tingkat kesukaannya dalam bentuk skor, yaitu:

1. Sangat tidak suka

2. Tidak suka

3. Agak suka

4. Suka

5. Sangat suka
Uji efektifitas dilakukan untuk menentukan perlakuan terbaik dari semua parameter yang diukur (de Garmo et al., 1994). Uji ini dilakukan untuk dengan cara memilih variabel-variabel yang diamati dalam alternatif tertentu yang diurutkan berdasarkan bobot (weight) tingkat prioritas tertentu. Bobot kemudian dinormalisasi dengan cara membagi masing-masing bobot dengan jumlah nilai bobot yang diberikan. Nilai efektifitas setelah itu ditentukan. Nilai efektivitas dihitung dengan mengikuti persamaan berikut:

\section{Nilai Efektifitas}

$=\frac{\text { Nilai hasil pengukuran }- \text { Nilai terburuk }}{(\text { Nilai terbaik }- \text { Nilai terburuk })}$

Nilai efektivitas yang diperoleh dikalikan dengan nilai normalisasi dari bobot yang diberikan untuk masing-masing parameter. Langkah terakhir hasil kali dari nilai efektivitas dengan nilai normalisasi dijumlahkan pada masing-masing alternatif. Nilai jumlah yang terbesar merupakan nilai perlakuan terbaik.

\section{HASIL DAN PEMBAHASAN}

\section{Karakteristik Fisik Amplang Lele Dumbo}

\section{Tekstur Amplang Lele Dumbo}

Jumlah penambahan tapioka pada adonan dapat meningkatkan tekstur amplang yang dihasilkan. Semakin banyak jumlah tapioka yang ditambahkan semakin keras tekstur amplang. Perlakuan P1 (proporsi ikan lele dan tapioka 1:1,25) memiliki nilai tekstur terendah. Semakin rendah hasil pengukuran tekstur semakin renyah tekstur amplang. Perlakuan P5 (proporsi ikan lele dan tapioka 1:2,25) memiliki nilai tekstur tertinggi (Gambar 1).

Semakin tinggi nilai tekstur semakin keras tekstur amplang. Hal ini diduga karena kandungan amilosa dalam pati tepung tapioka lebih banyak. Menurut 
Laiya et al. (2014), semakin rendah penggunaan tepung sagu akan mengakibatkan tekstur kerupuk ikan gabus berongga dan halus. Penggunaan tepung sagu terlalu banyak akan mengakibatkan tekstur yang semakin padat/keras.

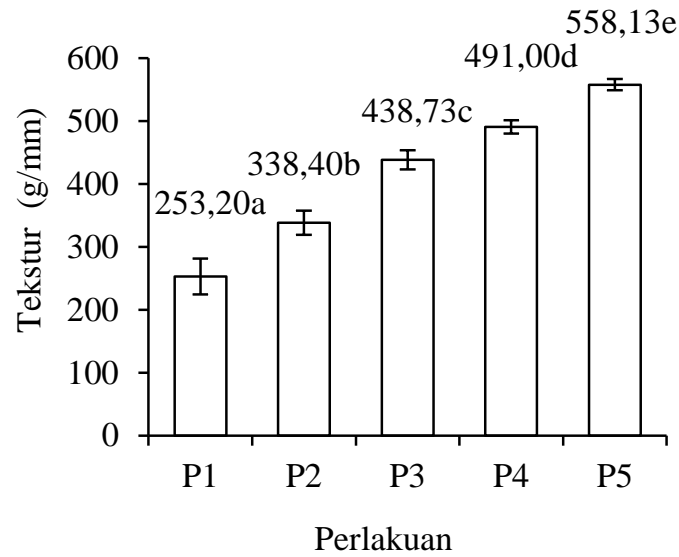

Gambar 1. Nilai tekstur amplang lele dumbo perlakuan rasio daging ikan dengan tapioka $(\mathrm{P} 1=1: 1,25 ; \mathrm{P} 2=1: 1,50 ; \mathrm{P} 3=$ $1: 1,75 ; \mathrm{P} 4=1: 2 ; \mathrm{P} 5=1: 2,25)$

Meningkatnya tekstur yang semakin keras ini bisa disebabkan oleh terbentuknya lapisan film hasil kombinasi protein dan pati yang semakin kuat seperti pada pembuatan edible film oleh Saleh et al. (2017), yang menyatakan bahwa semakin besar jumlah pati singkong maka kekuatan tarik edible semakin tinggi. Hal ini disebabkan oleh sifat dari ikatan biopolimer pada gel pati singkong semakin kuat dengan semakin banyaknya pati.

\section{Warna Amplang Lele Dumbo}

Jumlah penambahan tapioka pada adonan dapat menurunkan kecerahan warna amplang. Semakin banyak jumlah tapioka yang ditambahkan semakin rendah kecerahan warna amplang yang dihasilkan. Warna amplang lele dumbo berkisar antara 14,42 (P5) hingga 27,76 (P1). Perlakuan P1 (proporsi ikan lele dan tapioka 1:1,25) memiliki kecerahan tertinggi karena jumlah pati tapioka terendah. Sebaliknya perlakuan P5 (proporsi ikan lele dan tapioka 1:2,25) memiliki kecerahan terendah (Gambar 2). Pada uji anova warna amplang P1 dan P2 tidak berbeda nyata, tekstur P2 dan P3 berbeda nyata, tekstur P3 dan P4 tidak berbeda nyata, tekstur P4 dan P5 tidak berbeda nyata.

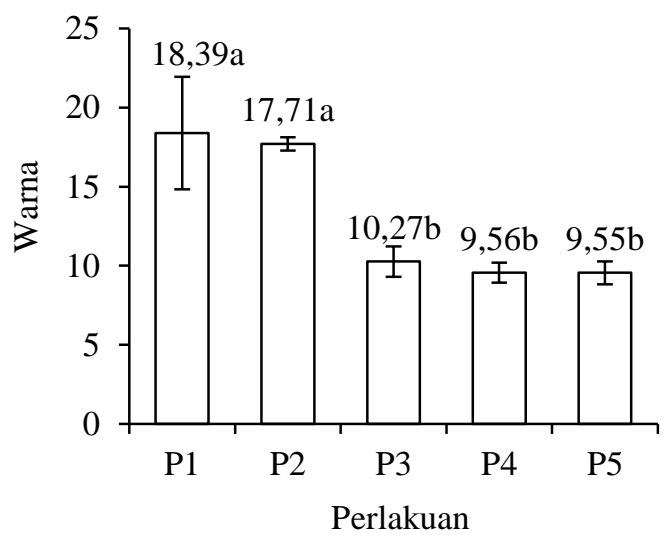

Gambar 2. Nilai kecerahan warna amplang lele dumbo perlakuan rasio daging ikan dengan tapioka $(\mathrm{P} 1=1: 1,25 ; \mathrm{P} 2=$ $1: 1,50 ; \mathrm{P} 3=1: 1,75 ; \mathrm{P} 4=1: 2 ; \mathrm{P} 5=$ $1: 2,25)$

Semakin banyak jumlah tapioka yang ditambahkan maka semakin rendah kecerahan warna amplang yang dihasilkan. Hal ini dikarenakan kandungan yang ada pada pati memiliki sifat akan berubah menjadi kecoklatan atau browning jika terkena panas (Koswara, 2009). Warna kerupuk semakin coklat dengan bertambahnya persentase penambahan daging. Hal ini dipengaruhi oleh adanya reaksi maillard. Perubahan warna kerupuk yang diakibatkan adanya reaksi pencoklatan non enzimatis dapat terjadi dikarenakan kandungan gizi kerupuk yang banyak mengandung karbohidrat dan sedikit protein, sehingga gula pereduksi akan bereaksi dengan gugus amina primer dari protein yang menghasilkan pigmen melanoidin yang dapat mengakibatkan warna coklat pada kerupuk (Ketaren, 1986). 


\section{Daya Kembang Amplang Lele Dumbo}

Jumlah penambahan tapioka pada adonan dapat menurunkankan daya kembang amplang. Semakin banyak jumlah tapioka yang ditambahkan semakin kecil daya kembang amplang yang dihasilkan.

Daya kembang amplang lele dumbo terbesar adalah perlakuan P1 pada proporsi ikan lele dan tapioka 1:1,25 yaitu sebesar $126,06 \%$, sedangkan Perlakuan P5 pada proporsi ikan lele dan tapioka 1:2,25 (P5) memiliki nilai daya kembang yang paling kecil yaitu 109,7\%. Daya kembang amplang lele ditunjukkan pada Gambar 3.

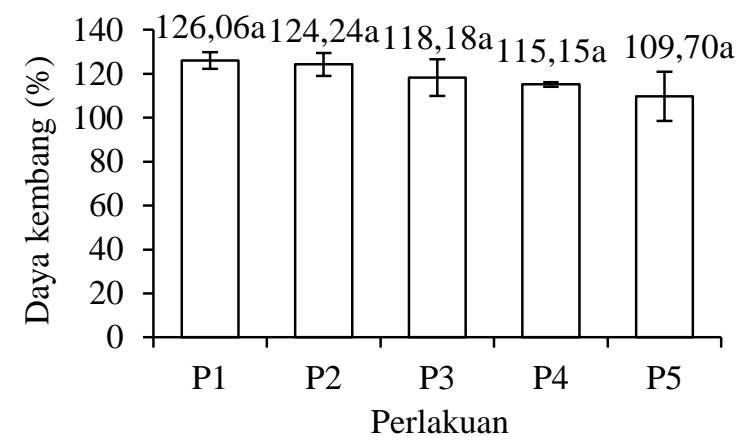

Gambar 3. Daya kembang amplang lele dumbo perlakuan rasio daging ikan dengan tapioka $(\mathrm{P} 1=1: 1,25 ; \mathrm{P} 2=1: 1,50 ; \mathrm{P} 3=$ $1: 1,75 ; \mathrm{P} 4=1: 2 ; \mathrm{P} 5=1: 2,25)$

Daya kembang amplang lele dumbo berkisar antara 126,06\% hingga 109,70\%. Pada uji anova pada taraf kepercayaan 5\%, daya kembang amplang antar perlakuan tidak berbeda nyata. Semakin banyak tapioka yang ditambahkan maka daya kembang amplang lele semakin kecil. Hal ini dikarenakan semakin banyak proporsi tapioka yang ditambahkan menyebabkan konsentrasi semakin pekat sehingga kemampuan untuk mengembang semakin kecil. Daya kembang merupakan atribut penting yang mempengaruhi kualitas kerupuk, karena daya kembang kerupuk menentukan kerenyahan kerupuk (Taewee, 2011). Fenomena pengembangan kerupuk disebabkan oleh tekanan uap yang terbentuk dari pemanasan kandungan air bahan, sehingga mendesak struktur bahan membentuk produk yang mengembang (Koswara, 2009).

\section{Higroskopisitas Amplang Lele Dumbo}

Penambahan jumlah tapioka dapat menurunkankan higroskopisitas amplang. Semakin banyak jumlah tapioka yang ditambahkan maka semakin kecil higroskopisitas amplang. Nilai higroskopisitas amplang lele dumbo menunjukkan bahwa perlakuan P1 pada proporsi ikan lele dan tapioka 1:1,25 memiliki higroskopisitas yang tertinggi yaitu $121,85 \%$, sedangkan perlakuan P5 pada proporsi ikan lele dan tapioka 1:2,25 memiliki higroskopisitas yang terendah yaitu sebesar 81,50 . Semakin rendah nilai higroskopisitas maka semakin lama daya simpan kerupuk amplang. Higroskopisitas amplang berhubungan dengan daya kembangnya, dimana daya kembang semakin tinggi makan higroskopisitasnya semakin tinggi karena semakin mudah menyerap uap air dari udara. Rongga udara lebih banyak sehingga uap air mudah masuk ke dalam amplang. Nilai higroskopisitas amplang lele dumbo ditunjukkan pada Gambar 4. Higroskopisitas amplang lele berkisar antara $121,85 \%$ hingga $81,50 \%$. Pada uji anova pada taraf kepercayaan 5\% higroskopisitas amplang antar perlakuan tidak berbeda nyata.

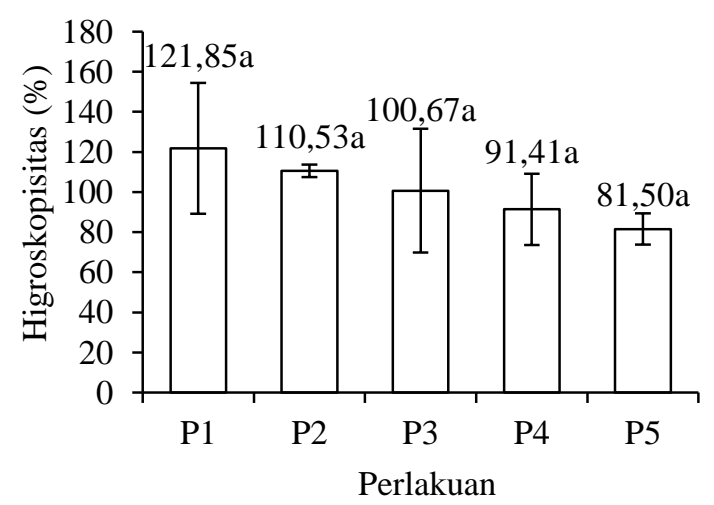

Gambar 4. Nilai higroskopisitas amplang lele dumbo perlakuan rasio daging ikan dengan tapioka $(\mathrm{P} 1=1: 1,25 ; \mathrm{P} 2=$ $1: 1,50 ; \mathrm{P} 3=1: 1,75 ; \mathrm{P} 4=1: 2 ; \mathrm{P} 5=$ $1: 2,25)$ 
Higroskopisitas merupakan atribut yang mempengaruhi kualitas kerupuk. Hal ini karena daya kembang kerupuk menentukan daya simpan kerupuk. Semakin rendah nilai higroskopisitas maka semakin lama daya simpan kerupuk amplang. Higroskopisitas amplang berhubungan dengan daya kembangnya, dimana daya kembang semakin tinggi, semakin tinggi higroskopisitasnya karena semakin mudah menyerap uap air dari udara (Setyowati, 2010). Faradilla (2019), menyebutkan bahwa daya kembang kerupuk yang semakin meningkat maka akan mudah menyerap udara karena rongga udara lebih banyak.

\section{Rendemen Amplang Lele Dumbo}

Penambahan jumlah tapioka dapat menurunkan rendemen amplang. Semakin banyak jumlah tapioka yang ditambahkan semakin rendah rendemen amplang. Perlakuan P1 pada proporsi ikan lele dan tapioka 1:1,25 memiliki rendemen yang tertinggi yaitu $121,85 \%$, sedangkan perlakuan P5 pada proporsi ikan lele dan tapioka 1:2,25 memiliki rendemen yang terendah yaitu sebesar 83,57\% (Gambar 5). Rendemen amplang lele dumbo berkisar antara $121,85 \%$ hingga $83,57 \%$. Pada uji anova pada taraf kepercayaan 5\%, rendemen amplang antar perlakuan tidak berbeda nyata.

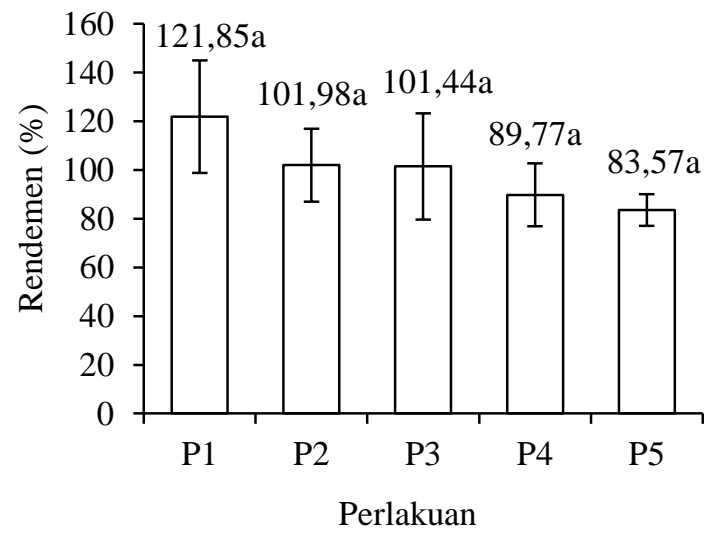

Gambar 5. Rendemen amplang lele dumbo perlakuan rasio daging ikan dengan tapioka $(\mathrm{P} 1=1: 1,25 ; \mathrm{P} 2=1: 1,50 ; \mathrm{P} 3=$ $1: 1,75 ; \mathrm{P} 4=1: 2 ; \mathrm{P} 5=1: 2,25)$

\section{Karakteristik Organoleptik Amplang Lele Dumbo}

Kerenyahan Amplang Lele Dumbo

Amplang lele yang banyak disukai panelis pada atribut kerenyahan adalah amplang lele dumbo pada perlakuan P5 (proporsi ikan lele dan tapioka 1:2,25). Nilai kesukaan atribut kerenyahan terendah pada perlakuan P2 (proporsi ikan lele dan tapioka 1:1,50). Kesukaan kerenyahan amplang lele pada proporsi ikan lele dan tapioka ditunjukkan pada Gambar 6.

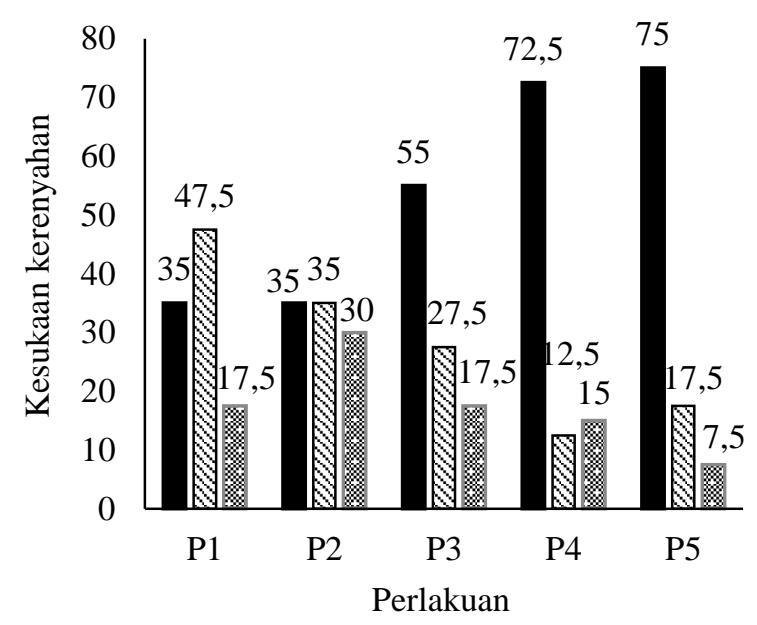

Gambar 6. Nilai kesukaan kerenyahan amplang lele dumbo perlakuan rasio daging ikan dengan tapioka $(\mathrm{P} 1=1: 1,25 ; \mathrm{P} 2=$ $1: 1,50 ; \mathrm{P} 3=1: 1,75 ; \mathrm{P} 4=1: 2 ; \mathrm{P} 5=$ $1: 2,25)$ dengan parameter sangat renyah-renyah $(\mathbf{O})$, agak renyah $(\mathbb{N})$, tidak renyah-sangat tidak renyah (

Nilai chi square kerenyahan amplang lebih besar dari nilai chi square taraf 0,05 yaitu 28,189>15,507. Proporsi ikan lele dan tapioka memberikan pengaruh yang nyata terhadap kesukaan kerenyahan amplang lele.

\section{Kesukaan Warna Amplang Lele Dumbo}

Amplang lele dumbo yang banyak disukai panelis pada atribut warna adalah amplang lele pada perlakuan P5 (amplang lele pada proporsi ikan lele dan tapioka 1:2,25). Selanjutnya kesukaan atribut warna terendah pada perlakuan P2 
(amplang lele pada proporsi ikan lele dan tapioka 1:1,50). Kesukaan warna amplang lele pada proporsi ikan lele dan tapioka ditunjukkan pada Gambar 7.

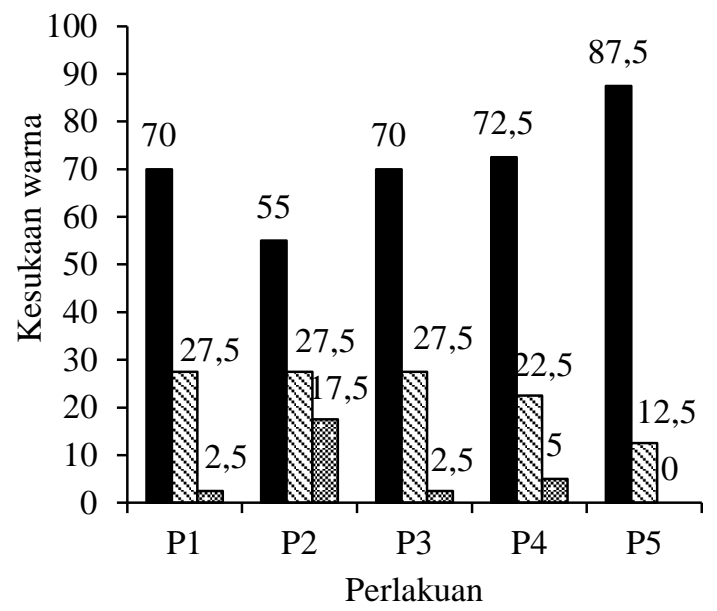

Gambar 7. Nilai kesukaan warna amplang lele perlakuan rasio daging ikan dengan tapioka $(\mathrm{P} 1=1: 1,25 ; \mathrm{P} 2=1: 1,50 ; \mathrm{P} 3=$ $1: 1,75 ; \mathrm{P} 4=1: 2 ; \mathrm{P} 5=1: 2,25)$ dengan parameter sangat renyah-renyah $(\mathbf{)})$, agak renyah $(\mathbb{N})$, tidak renyah-sangat tidak renyah (

Nilai chi square warna amplang lebih besar dari nilai chi square tabel 0,05 yaitu 19,894>15,507. Hasil analisis chi square menunjukkan bahwa proporsi ikan lele dan tapioka memberikan pengaruh yang nyata terhadap kesukaan warna amplang lele.

\section{Kesukaan Rasa Amplang Lele Dumbo}

Amplang lele dumbo yang banyak disukai panelis pada atribut rasa adalah amplang lele pada perlakuan P5 (amplang lele pada proporsi ikan lele dan tapioka 1:2,25) dan P3 (amplang lele pada proporsi ikan lele dan tapioka 1:1,75). Kesukaan atribut rasa terendah pada perlakuan P1 (amplang lele pada proporsi ikan lele dan tapioka 1:1,25). Kesukaan rasa amplang lele pada Proporsi ikan lele dan tapioka ditunjukkan pada Gambar 8.
Nilai chi square rasa amplang lebih besar dari nilai chi square tabel 0,05 yaitu 17,794>15,507. Proporsi ikan lele dan tapioka memberikan pengaruh yang nyata terhadap kesukaan rasa amplang lele.

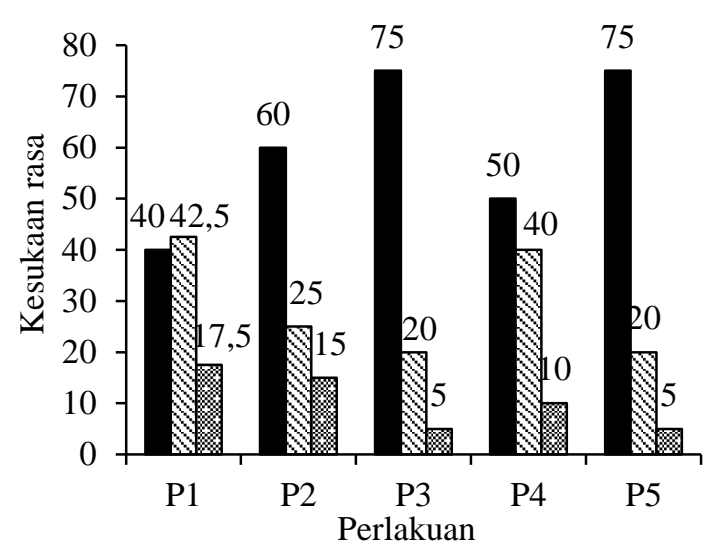

Gambar 8. Nilai kesukaan rasa amplang lele perlakuan rasio daging ikan dengan tapioka $(\mathrm{P} 1=1: 1,25 ; \mathrm{P} 2=1: 1,50 ; \mathrm{P} 3=$ $1: 1,75 ; \mathrm{P} 4=1: 2 ; \mathrm{P} 5=1: 2,25)$ dengan parameter sangat renyah-renyah ( $)$, agak renyah $(\mathbb{N})$, tidak renyah-sangat tidak renyah (이잉

\section{Kesukaan Keseluruhan Amplang Lele Dumbo}

Amplang lele dumbo yang banyak disukai panelis pada atribut keseluruhan adalah amplang lele pada perlakuan P5 (amplang lele pada proporsi ikan lele dan tapioka 1:2,25). Atribut keseluruhan terendah pada perlakuan P2 (amplang lele pada proporsi ikan lele dan tapioka 1:1,50). Kesukaan warna amplang lele pada proporsi ikan lele dan tapioka ditunjukkan pada Gambar 9.

Nilai chi square warna amplang lebih besar dari nilai chi square tabel 0,05 yaitu 26,552>15,507. Hasil analisis chi square menunjukkan bahwa proporsi ikan lele dan tapioka memberikan pengaruh yang nyata terhadap kesukaan warna amplang lele. 


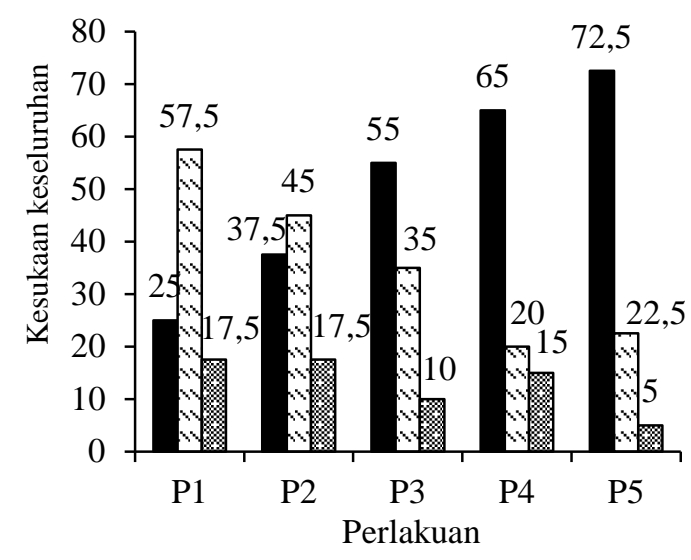

Gambar 9. Nilai kesukaan keseluruhan amplang lele perlakuan rasio daging ikan dengan tapioka $(\mathrm{P} 1=1: 1,25, \mathrm{P} 2=1: 1,50, \mathrm{P} 3=$ $1: 1,75, \mathrm{P} 4=1: 2, \mathrm{P} 5=1: 2,25)$ dengan parameter sangat renyah-renyah $(\mathbf{G})$, agak renyah $(\mathbb{N})$, tidak renyah-sangat tidak renyah (

\section{Perlakuan Terbaik Amplang Lele Dumbo}

Penentuan perlakuan terbaik menggunakan uji efektivitas bertujuan untuk memilih satu perlakuan yang akan dilanjutkan dan dikembangkan pada tahap penelitian berikutnya. Parameter dalam penentuan perlakuan terbaik amplang lele dumbo meliputi karakteristik organoleptik dan karakteristik fisik dari lima perlakuan.

Bobot yang diberikan pada setiap parameter berbeda. Bobot untuk parameter organoleptik kerenyahan sebesar 1,0; organoleptik warna 1,0 ; organoleptik rasa 1,0; organoleptik keseluruhan 1,0; tekstur sebesar 0,9 ; warna 0,8 ; daya kembang sebesar 0,9; higroskopisitas sebesar 0,8; dan rendemen 0,9 . Nilai indeks efektivitas ditunjukkan pada Tabel 2.

Tabel 2. Nilai indeks efektivitas amplang lele dumbo

\begin{tabular}{cc}
\hline Perlakuan & Nilai efektivitas \\
\hline P1 & 0,477 \\
P2 & 0,401 \\
P3 & 0,432 \\
P4 & 0,387 \\
P5 & 0,482 \\
\hline
\end{tabular}

Perlakuan terbaik adalah perlakuan P5 karena memiliki nilai efektivitas tertinggi yaitu 0,482 (Tabel 2). Perlakuan P5 yaitu amplang lele dumbo pada pada proporsi ikan lele dan tapioka 1:2,25. Amplang lele perlakuan tersebut memiliki skor kerenyahan 5,58; warna 9,55 ; daya kembang 109,7\%; rendemen 83,57\%; kadar air $1,80 \%$; kadar abu 2,08\%; kadar protein $5,75 \%$; kadar lemak 23,44\%; kadar karbohidrat 66,93\%; kesukaan kerenyahan dari sangat suka hingga suka (75\%); kesukaan warna dari sangat suka hingga suka $(87,5 \%)$; kesukaan rasa dari sangat suka hingga suka (75\%); dan kesukaan keseluruhan dari sangat suka hingga suka $(72,5 \%)$.

\section{Karakteristik Kimia Amplang Lele Dumbo \\ Kandungan gizi amplang lele} dumbo secara umum telah memenuhi syarat sesuai SNI 7762-2013. Kandungan gizi amplang lele dumbo ditunjukkan pada Tabel 3.

Tabel 3. Perbandingan kandungan gizi amplang lele dumbo dan SNI amplang ikan (SNI 77622013)

\begin{tabular}{lcc}
\hline Kandungan gizi & $\begin{array}{c}\text { Berdasarkan } \\
\text { SNI* }\end{array}$ & $\begin{array}{c}\text { Amplang } \\
\text { lele dumbo } \\
\text { (P5) }\end{array}$ \\
\hline Kadar air & Maksimal 4\% & $1,80 \%$ \\
Kadar abu & Maksimal 5\% & $2,08 \%$ \\
Kadar lemak & Maksimal 35,0\% & $23,44 \%$ \\
Kadar protein & Minimal 7\% & $5,75 \%$ \\
Kadar karbohidrat & - & $66,93 \%$ \\
\hline
\end{tabular}

*Sumber: Badan Standardisasi Nasional Indonesia, 2013

Kadar air amplang lele dumbo adalah $1,81 \%$. Kadar air ini dibawah SNI 77622013 yaitu maksimal 4,0 \%. Kadar abu amplang lele perlakuan terbaik P5 adalah 2,08\%. Kadar abu ini lebih rendah dari SNI 7762-2013 yang maksimal 5\%. Kadar protein amplang lele pada perlakuan terbaik P5 adalah 5,75\%. Kadar protein ini lebih 
rendah dari SNI yaitu minimal 7,0\%. Kadar protein pada perlakuan terbaik P5 lebih rendah dari SNI. Hal ini disebabkan proporsi tepung tapioka yang ditambahkan besar. Kadar lemak amplang lele perlakuan terbaik P5 adalah 23,44\%. Kadar lemak ini lebih rendah dari SNI yaitu maksimal $35,0 \%$. Selama penggorengan sebagian minyak masuk ke dalam matriks amplang lele dan mengisi ruang kosong atau rongga akibat penguapan air. Kadar karbohidrat amplang lele adalah 66,93\% ditentukan dari hasil pengurangan $100 \%$ dengan kadar air, kadar abu, kadar lemak, dan kadar protein (by difference). Kadar karbohidrat produk olahan yang dihitung sangat tergantung dari faktor pengurang yang berasal dari bahan tambahan selama proses pengolahan (Winarno, 2002).

\section{KESIMPULAN}

Rasio ikan lele dumbo dan tapioka dalam adonan berpengaruh nyata terhadap tekstur dan warna amplang. Perubahan tekstur amplang ini berdampak pada tingkat kesukaan panelis, diperkuat dengan hasil uji organoleptik yang menunjukkan bahwa parameter kerenyahan, warna, dan rasa mengakibatkan perbedaan tingkat kesukaan panelis terhadap amplang ikan lele dumbo. Perlakuan yang menghasilkan amplang lele dumbo paling disukai oleh panelis adalah proporsi ikan lele dan tapioka 1:2,25. Amplang ikan lele hasil formulasi ini memiliki kadar air 1,80\%; kadar abu 2,08\%; kadar protein 5,75\%; kadar lemak $23,55 \%$; dan kadar karbohidrat 66,93\%.

\section{DAFTAR PUSTAKA}

AOAC. 2005. Official Method of Analysis of the Association of Official Analitycal Chemists. 18th ed. Maryland: AOAC International. William Harwitz (ed), United States of America.
Badan Standardisasi Nasional Indonesia. 2013. SNI 7762-2013. Amplang ikan: Syarat mutu dan keamanan produk. Badan Standardisasi Nasional Indonesia, Jakarta. (https://fdokumen.site/document/ampsni-7762-2013-amplang-ikan.html). [Diakses tanggal 15 Juli 2020].

de Garmo, E. D., Sullivan, W.G., and Canada, J.R. 1984. Engineering economis. Mc Millan Publishing Company, New York.

Fardiaz, D. 1984. Teknik Analisa Sifat Fungsional Komponen Bahan Pangan. Pusat Antar Universitas Institut Pertanian Bogor, Bogor.

Faradilla, S. 2019. Pengaruh penanganan bahan baku ikan lele dumbo (Clarias gariepinus) yang berbeda terhadap mutu kerupuk amplang. Jurnal Fakultas Perikanan \& Kelautan, Universitas Riau, Pekanbaru, pp. 1-12.

Kementerian Kelautan dan Perikanan. 2018. Peta sentra produksi perikanan budidaya. Direktrat Produksi dan Usaha Budidaya, Kementerian Kelautan dan Perikanan, Jakarta. (https://kkp.go.id/an -component/media/upload-gambar-pen dukung/kkp/DATA\%20KKP/Bahan\%2 0RO\%20KKP\%202018\%20(final).pdf). [Diakses tanggal 27 Juli 2020].

Ketaren, S. 1986. Pengantar Teknologi Minyak dan Lemak Pangan. UI-Press, Jakarta.

Koswara, S. 2009. Pengolahan Aneka Kerupuk. Ebookpangan.com.

Laiya, N., Harmain, R.M., dan Yusuf, N. 2014. Formulasi kerupuk ikan gabus yang disubtitusi dengan tepung sagu. Jurnal Ilmiah Perikanan dan Kelautan, 2 (2): 81-87.

Listyarini, S., Santoso, J., dan Asriani, A. 2018. Konsentrat protein ikan lele dumbo (Clarias gariepenus) afkir dalam kerupuk melarat untuk mencapai sustainable development goals. Jurnal Matematika, Sains, dan Teknologi, 19 (2): 106-113. 
Nurilmala, M., Nurjanah, dan Utama, R.H. 2009. Kemunduran mutu ikan lele dumbo (Clarias gariepinus) pada penyimpanan suhu chilling dengan perlakuan cara mati. Jurnal Pengolahan Hasil Perikanan Indonesia, 12 (1): 1-16.

Pradita, D. 2016. "Karakteristik Amplang Lele Dumbo (Clarias gariepinus) yang Dibuat dengan Variasi Jenis dan Jumlah Pati”. Skripsi. Fakultas Teknologi Pertanian, Universitas Jember, Jember.

Rohimah, I., Etti, S., dan Ernawati, N. 2014. Analisis energi dan protein serta daya terima biskuit tepung labu kuning dan ikan lele. Jurnal USU. https://jurnal.usu.ac.id/index.php/gkre/a rticle/view/5160/2781. [Diakses tanggal 15 Juli 2020].

Rosa, R., Bandarra, N.M., dan Nunes, M.I. 2007. Nutritional quality of African cat fish Clarias gariepinus (Burchell 1822): A positive criterion for the Future development of the European production of Siluroidei. International Journal of Food Science \& Technology, 42 (3): 342-351.

Saleh, F.H.M., Nugroho, A.Y., dan Juliantomo, M.R. 2017. Pembuatan edible film dari pati singkong sebagai pengemas makanan. Teknoin (Jurnal Teknologi Industri), 23 (1): 43-48.

Setyaningsih, D., Apriyantono, A., dan Maya, P.S. 2010. Analisis Sensori untuk Industri Pangan dan Agro. IPB Press, Bogor.

Setyowati, A. 2010. Penambahan natrium tripolifosfat dan CMC (carboxxy methyl selulose) pada pembuatan karak. Jurnal Agrisains, 1 (1): 40-49.

Sudarmadji, S., Haryono, B. dan Suhardi. 1997. Prosedur Analisa untuk Bahan Makanan dan Pertanian. Liberty, Yogyakarta.

Suyatno, 2010. Daftar Komposisi Bahan Makanan (DKBM). Materi kuliah Survilliance Gizi. Fakultas Ilmu Kesehatan. Universitas Diponegoro. Semarang.
Taewee, T.K. 2011. Mini review cracker "Keropok": Review on factor influencing expansion. International Food Research Journal, 18 (3): 855866.

Winarno. 2002. Kimia Pangan dan Gizi. Gramedia, Jakarta. 